\title{
Plant uptake potential of endosulfan from soil by carrot and spinach
}

\author{
Geun-Hyoung Choi ${ }^{1} \cdot$ Dong-Kyu Jeong ${ }^{2} \cdot$ Sung-Jin Lim ${ }^{1} \cdot J^{\prime}$-Ho Ro ${ }^{1} \cdot$ \\ Song-Hee Ryu ${ }^{1} \cdot$ Byung-Jun Park $^{1} \cdot$ Byung-Cheol Moon $^{1} \cdot$ Jin Hyo Kim$^{2}$ [D

\section{다소비 채소작물인 시금치와 당근의 토양 중 엔도설판 흡수이행능}

최근형 ${ }^{1} \cdot$ 정동규 $^{2} \cdot$ 임성진 $^{1} \cdot$ 노진호 $^{1} \cdot$ 류송희 $^{1} \cdot$ 박병준 $^{1} \cdot$ 문병철 $^{1} \cdot$ 김진효 $^{2}$

Received: 14 August 2017 / Accepted: 19 September 2017 / Published Online: 31 December 2017

(C) The Korean Society for Applied Biological Chemistry 2017

\begin{abstract}
Residual endosulfan in an agricultural environment has been reported, although endosulfan was listed to persistent organic pollutants and banned. To produce the safe crop from endosulfan residue risk, the plant uptake potential of endosulfan from soil to crop should be studied. In here, the plant uptake potentials of endosulfan in various crops were surveyed and ranged from 0.002-4.460. And the bioconcentration factors (BCF) of total endosulfan in carrot and spinach were calculated from the pot experiment. The BCFs in carrot and spinach were 0.285 and $0.040-0.047$ respectively. Endosulfan sulfate was contributed to over $42.8 \%$ of the crop residue as a major contributor among the three endosulfan congeners in both of carrot and spinach.
\end{abstract}

Keywords Bioconcentration factor $\cdot$ Carrot $\cdot$ Endosulfan $\cdot$ Plant uptake $\cdot$ Spinach

Jin Hyo Kim $(\bowtie)$

E-mail: jhkim75@gnu.ac.kr

${ }^{1}$ Chemical Safety Division, National Institute of Agricultural Sciences, RDA, Wanju, Republic of Korea

${ }^{2}$ Division of Applied Life Science (BK21 plus), Institute of Agriculture and Life Science (IALS), Gyeongsang National University, Jinju, Republic of Korea

This is an Open Access article distributed under the terms of the Creative Commons Attribution Non-Commercial License (http://creativecommons. org/licenses/by-nc/3.0/) which permits unrestricted non-commercial use, distribution, and reproduction in any medium, provided the original work is properly cited.

\section{서 론}

과거 유기염소계 살충제로 흔히 사용되던 endosulfan은 높은 생 물농축성과 독성, 그리고 장거리 이동성으로 인해 잔류성유기오 염물질(Persistent Organic Pollutants, POPs)로 규정되어 국제적 으로 생산 및 사용이 금지되었다(Choi 등, 2017). 우리나라에서 는 2011년 endosulfan에 대한 농약등록이 취소되었고, 2015년 환경부 잔류성유기오염물질 목록에 등록되어 환경 잔류 endosulfan에 대한 관리가 한층 강화되었다(Ahn 등, 2017). 하 지만, 등록 취소 전까지 endosulfan의 생산 및 출하량이 연간 $100 \mathrm{M} / \mathrm{T}$ 수준이었고, 농약등록 취소 이후에도 endosulfan에 대한 국내 농산물 중 잔류 보고와 가축 중독, 축산물 중 잔류 보고가 계속되고 있다(Lee 등, 2013; Hwang 등, 2016). 이는 endosulfan 이 환경 중 잔류성이 높아 등록 취소 이전에 사용된 농약이 토 양에 잔류하면서 높은 생물농축성으로 인해 토양에서 작물로 흡 수이행 되어 나타난 결과로 보여진다. 하지만, 무, 상추 등 일 부 작물에 대해서만 endosulfan의 작물흡수 이행성이 조사되었 을 뿐 시금치, 당근 등 다소비 다빈도 섭취 채소류에 대한 작 물흡수 이행성에 대한 분석 연구는 여전히 부족하다.

시금치는 비타민 $\mathrm{A}$ 와 비타민 $\mathrm{C}$ 의 주요 공급원으로 알려져 있 으며, 2016년 기준 생산 면적이 $5,149 \mathrm{ha}$, 생산량은 $72,892 \mathrm{M} / \mathrm{T}$ 으 로 국내 20대 주요 농산물 품목으로 관리되고 있다(KOSIS 2017). 특히 시금치의 경우 잔류농약 부적합 비율이 2017년 보고서 기 준 9.2\% 수준으로 전체 잔류농약 부적합률 $3.4 \%$ 보다 높은 수준 을 나타내었고, 당근은 베타카로틴이 함유된 대표적인 근채류로 서 국내 생산량 상위 품목으로 국내 생산면적 2,230 ha, 생산량 $73,061 \mathrm{M} / \mathrm{T}$ (2016 기준)을 나타내었다(NAQS 2017). 잔류농약 부 적합률은 평균 수준인 3.5\%를 나타내었으나, 2018년 이후 전격적 으로 시행될 Positive-List-System (PLS) 제도에 따라 현재 사용되 고 있는 농약에 대한 안전 관리 강화와 함께 재배 환경 잔류 오 염물질인 POPs에 대한 작물 잔류 연구도 필요하다. 특히, PLS제 
도 시행에 따라 endosulfan에 대한 작물 잔류허용기준은 모든 작 물에서 최저 기준인 $0.01 \mathrm{mg} \mathrm{kg}^{-1}$ 을 적용 받게 되어 일부 endosulfan에 대한 작물 흡수이행능이 높은 작물에 대해서는 작물 별 Extraneous Maximum Residue Limits (EMRL) 설정 등을 통 해 국내 농산물 생산시장을 안정화 할 필요가 있다. 이를 위해서 는 endosulfan에 대한 작물 별 흡수이행능을 분석함으로써 안전농 산물 재배를 위한 농경지 안전관리 가이드라인을 마련할 수 있을 것이다. 따라서, 본 연구에서는 작물에 대한 endosulfan의 흡수이 행에 관한 연구결과를 분석하고, 이를 통해 다소비 채소작물인 시 금치와 당근에 대한 잔류이행성을 비교 분석하여 환경 잔류 POPs 물질이 작물 잔류에 미치는 영향을 평가하였다.

\section{재료 및 방법}

\section{표준품 및 시약}

Endosulfan 표준품( $\alpha$-endosulfan, $\beta$-endosulfan, endosulfan sulfate) 은 Dr. Ehrenstorfer GmbH (Augsburg, Germany)제품을 사용 하였고, 토양처리에 사용된 endosulfan은 $35 \%$ 유제(한국삼공, Seoul, Republic of Korea)와 3\% 분제(동부팜한농, Seoul, Republic of Korea)를 시중에서 구매하여 사용하였다. 시험에 사 용된 용매인 acetone, n-hexane, dichloromethane (DCM)과 $\mathrm{NaCl}$, 무수 $\mathrm{Na}_{2} \mathrm{SO}_{4}$, Florisil은 Merck 사(Darmstadt, Germany) 제품을 사용하였다.

\section{시금치 Pot 시험}

시금치 재배에 사용한 토양은 전라북도 완주군 국립농업과학원 밭포장에서 채취하여 7일간 음건한 후 $2 \mathrm{~mm}$ 체로 쳐서 사용하 였다. 체친 토양에 지오릭스 유제(endosulfan $35 \%$ ) 희석액을 첨 가하여 명목상 농도가 $5 \mathrm{mg} \mathrm{kg}^{-1}$ (Treat I)과 $20 \mathrm{mg} \mathrm{kg}^{-1}$ (Treat II)이 되도록 처리한 후 회전식 토양 교반기로 균질화하였다. 오 염처리된 토양을 $1 / 2,000 \mathrm{a}$ 와그너 포트에 나눠 담고 함수율 $30-40 \%$ 를 유지하며 1 개월간 숙성시켰다. 시금치는 봄여름재배 용 시금치(킹오브덴마크, 아시아종묘, Seoul, Republic of Korea) 를 구매하여 포트에 파종하였다. 파종 후 60 일간 재배한 시금 치를 수확하여 뿌리를 제거한 후 흐르는 물로 겉에 묻은 흙을 제거하였다. 시금치의 물기를 제거한 후 드라이아이스를 넣고 분쇄하여 분석 전까지 $-20{ }^{\circ} \mathrm{C}$ 에서 냉동 보관하였다. 시금치 수 확 시 토양을 채취하여 실험실에서 음건한 후 시금치와 함께 냉동 보관하며 분석시료로 사용하였다.

\section{당근 Pot 시험}

실험에 사용한 토양은 경기도 수원시 소재 국립농업과학원 시 험포장 밭토양을 채취하여 음건한 후 $2 \mathrm{~mm}$ 체로 쳐서 사용하였 다. 체친 토양과 원예용 상토를 부피비 $4 / 1$ 로 섞은 다음, 지오 릭스 분제(endosulfan $3 \%$ ) $1.4 \mathrm{~g}$ 을 $2.0 \mathrm{~kg}$ 토양과 교반하여 균 질화 하였으며, 명목상 처리농도는 $21 \mathrm{mg} \mathrm{kg}^{-1}$ (Treat III)이었다. 처리한 토양을 실험용 포트(내경 $170 \mathrm{~mm} \times$ 높이 $140 \mathrm{~mm}$ )에 담 고 함수율 $30-40 \%$ 를 유지하며 10 일간 숙성시켰다. 실험용 당 근은 세장형 미니당근(아시아베이비, 아시아종묘)을 구매하여 숙 성된 포트에 파종하였고, 파종 후 140 일에 수확하였다. 토양 시 료는 채취 후 음건하여 냉동보관 하였고, 당근 시료는 흐르는
물로 흙을 제거하고 뿌리와 잎을 분리 하였다. 물기가 제거된 당근은 드라이아이스를 넣고 균질화 하고, 분석 전까지 $-20{ }^{\circ} \mathrm{C}$ 에서 냉동보관 하였다.

\section{시료 전처리}

토양시료와 작물시료는 Park 등(2004)이 보고한 방법과 같이 수 행되었으며, 간단히 정리하면 다음과 같다. $100 \mathrm{~mL}$ acetone을 사용하여 $25 \mathrm{~g}$ 의 시료를 추출하고 고형분을 걸러내고 제거하였 다. 추출액은 농축 후 $10 \mathrm{~mL}$ acetone에 재용해 후 분액여두에 옮기고 $10 \mathrm{~mL}$ 포화 $\mathrm{NaCl}$ 용액과 $50 \mathrm{~mL}$ 증류수 $(\mathrm{DW})$ 를 넣고 $\mathrm{DCM}(50 \mathrm{~mL} \times 3)$ 으로 추출하였다. 유기용매층은 무수 $\mathrm{Na}_{2} \mathrm{SO}_{4}$ 를 사용하여 탈수시킨 뒤 감압농축기를 사용하여 농축하였다. 농축 액은 $\mathrm{n}$-hexane $2 \mathrm{~mL}$ 에 재용해 하였고, $130^{\circ} \mathrm{C}$ 에서 48 시간 동안 활성화된 Florisil $(0.150-0.250 \mathrm{~mm})$ 로 사용하여 정제하였다. 정 제액은 농축 후 $\mathrm{n}$-hexane $2 \mathrm{~mL}$ 로 재 용해하여 gas chromatography $(\mathrm{GC})$ 를 사용하여 기기분석에 사용하였다.

\section{정량기기분석}

Endosulfan은 GC-micro electron capture detection ( $\mu \mathrm{ECD})$ (Agilent Technologies 6890, CA, USA)에서 Rtx-5 column ( $30 \mathrm{~m} \times 0.25 \mathrm{~mm}, 0.25 \mu \mathrm{m}$, Restek, Bellefonte, PA, USA)을 사 용하였다. 이동상은 질소를 사용하였고, 시료는 splitless 조건에 서 $1 \mu \mathrm{L}$ 를 주입하였다. 시료 주입기의 온도와 검출기의 온도는 각각 $230{ }^{\circ} \mathrm{C}$ 와 $300{ }^{\circ} \mathrm{C}$ 를 유지하였고, 오븐 온도는 $150{ }^{\circ} \mathrm{C}$ 에서

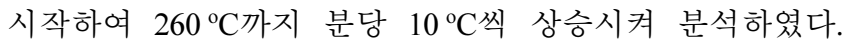
Calibration curve는 $0.001-0.5 \mathrm{mg} \mathrm{L}^{-1}$ 범위에서 작성하였고, $\alpha$ endosulfan, $\beta$-endosulfan 그리고 endosulfan sulfate 모두 $\mathrm{R}^{2}$ 가 0.999 이상 양호하였다. 본 시험의 정량한계는 $\alpha$-endosulfan과 $\beta$-endosulfan, endosulfan sulfate가 각각 $0.0001,0.0001$ 과 $0.0005 \mathrm{mg} \mathrm{kg}^{-1}$ 으로 확인되었으며, 토양시료와 시금치, 당근에서 의 회수율은 $0.01 \mathrm{mg} \mathrm{kg}^{-1}$ 과 $0.1 \mathrm{mg} \mathrm{kg}$ 에서 $78-96 \%$ 였고, 상대 표준편차는 8.7-9.8\% 로 양호하였다.

\section{생물농축계수 (BCF)}

총 endosulfan은 $\alpha$-endosulfan, $\beta$-endosulfan과 endosulfan sulfate 의 합으로 산출하였으며, bioconcentration factors $(\mathrm{BCF})$ 는 Hwang 등(2016)이 사용한 방법에 따라 작물 파종 시점의 토양 잔류농도 $\left(\mathrm{C}_{\mathrm{soil}}\right)$ 를 기준으로 endosulfan의 식물 잔류농도 $\left(\mathrm{C}_{\mathrm{plant}}\right)$ 를 사용하여 아래의 식과 같이 산출하였다.

$$
\mathrm{BCF}=\mathrm{C}_{\text {plant }} / \mathrm{C}_{\text {soil }}
$$

\section{통계처리}

시험 시료는 총 10 개의 반복 처리구로부터 확보한 결과를 바탕 으로, 통계프로그램 R (ver. 3.2)을 사용하여 Duncan test $(p<0.05)$ 를 수행하여 평가하였다.

\section{결과 및 고찰}

\section{Endosulfan의 작물흡수이행능 조사}

토양 잔류 유기오염물질이 식물로 흡수 이행되는 경로는 식물 뿌리를 통한 흡수와 기화를 통한 잎을 통해 흡수되는 경로로 
Table 1 The residual endosulfan concentration $\left(\mathrm{mg} \mathrm{kg}^{-1}\right)$ in the experimental soil

\begin{tabular}{|c|c|c|c|c|c|}
\hline & \multirow{2}{*}{$\frac{\text { At seedling }}{\text { Total endosulfan }}$} & \multicolumn{4}{|c|}{ At harvest } \\
\hline & & $\alpha$-endosulfan & $\beta$-endosulfan & Endosulfan sulfate & Total endosulfan \\
\hline Treat I & 4.213 & $0.217(12.8 \%)^{*}$ & $0.533(32.7 \%)$ & $0.937(55.5 \%)$ & 1.687 \\
\hline Treat II & 16.18 & $2.301(23.9 \%)$ & $4.018(41.7 \%)$ & $3.307(34.3 \%)$ & 9.627 \\
\hline Treat III & 18.63 & $1.577(23.3 \%)$ & $2.664(39.4 \%)$ & $2.510(37.1 \%)$ & 6.751 \\
\hline
\end{tabular}

*Contribution ratio of three endosulfan congeners in total endosulfan residue

Table 2 The residual endosulfan concentration $\left(\mathrm{mg} \mathrm{kg}^{-1}\right)$ and the BCF for carrot and spinach

\begin{tabular}{|c|c|c|c|c|c|c|c|}
\hline & & \multicolumn{4}{|c|}{ Endosulfan } & \multirow{2}{*}{ Crop growth (g) } & \multirow{2}{*}{$\mathrm{BCF}^{*}$} \\
\hline & & $\alpha-$ & $\beta-$ & -sulfate & Total & & \\
\hline Spinach & Treat I & 0.015 & 0.048 & 0.135 & 0.198 & 16.9 & 0.047 \\
\hline Spinach & Treat II & 0.137 & 0.144 & 0.367 & 0.648 & 16.1 & 0.040 \\
\hline Carrot & Treat III & 1.404 & 1.639 & 2.280 & 5.323 & 226.2 & 0.285 \\
\hline
\end{tabular}

*BCF was based on the total endosulfan concentration

구분되며, 잔류 물질의 흡수이행 정도를 총량적 개념으로 나타 내는 방법으로 $\mathrm{BCF}$ 와 식물흡수이행률(plant uptake ratio, PUR) 을 흔히 사용하고 있다. BCF는 토양 오염농도를 기준으로 산 출하며, 연구자에 따라 파종시점 초기 잔류농도(Hwang 등, 2016) 혹은 수확시점 잔류농도(Manirakiza 등, 2003)를 사용하 고 있다. $\mathrm{BCF}$ 산출시 파종 시점의 초기 잔류농도를 사용할 경 우 새롭게 오염된 유기오염 물질이 토양 근권에서의 이탈, 분 해, 부동화 등 다양한 요인에 의해 잔류 농도가 변화되는 것을 포함하고 있다. 이 경우 $\mathrm{BCF}$ 는 작물 재배기간, 토양 오염 후 숙성기간, 오염물질의 토양 중 반감기, 혹은 토양 교질의 특징 에 따른 오염물질의 흡착성 등 여러 요인에 의해 달라질 수 있 으나, 작물 수확 시 작물내 잔류농도를 예측할 수 있는 장점이 있다. 하지만, 이미 오랜 시간 동안 토양에 잔류한 유기오염물 질의 경우, 오염토양 내 미생물상 안정화와 토양 교질과의 흡 착평형 도달 등으로 인해 토양 중 분해 반감기나 용탈률 등이 신규오염 조건과 크게 달라질 수 있다. 따라서, $\mathrm{POPs}$ 와 같은 난분해성 유기오염물질의 경우 신규오염 여지가 적어, $\mathrm{BCF}$ 산 출시 수확시점 잔류농도를 사용하여도 토양 잔류농도 변화가 크 지 않을 것으로 예상되어 여러 연구자들이 모니터링 조사를 통 한 $\mathrm{BCF}$ 평가연구에 활용하고 있다(Manirakiza 등, 2003).

최근 연구된 작물의 endosulfan 흡수이행능에 관한 결과를 살 펴보면 엽채류인 참나물과 상추, 배추의 $\mathrm{BCF}$ 는 각각 0.353 과 0.00-0.130, 0.009-0.040 (Manirakiza 등, 2003; Park 등, 2004; Esteve-Turrillas 등, 2005; Choi 등, 2011; Hwang 등, 2016)로 보고되었고, 근채류인 무, 당근, 고구마, 양파의 $\mathrm{BCF}$ 는 각각 0.003-0.66와 0.033-0.040, 0.00, 4.46로 보고되었으며(Manirakiza 등, 2003; Park 등, 2004; Hwang 등, 2016), 과채류인 오이, 가 지, 토마토, 고추 의 $\mathrm{BCF}$ 는 $0.00,0.48-2.0,0.00-0.28,0.00-0.02$ 로 확인되었고, endosulfan이 최대 $40 \mathrm{mg} \mathrm{kg}^{-1}$ 수준으로 오염된 토양에서도 오이의 가식부인 열매에서는 잔류량이 검출되지 않 았다는 보고가 있었다(Manirakiza 등, 2003; Hwang 등, 2015). 또한, 작물 잎에서의 $\mathrm{BCF}$ 는 토마토(0.04-0.09), 해바라기 (0.002$0.8)$, 대두(0.004-1.5)에서 보고되었고, 알팔파의 지상부 $\mathrm{BCF}$ 는 0.05-0.07로 보고된 바 있다(Mitton 등, 2016). 이러한 시험결과 를 정리하면, endosulfan에 대한 채소류의 $\mathrm{BCF}$ 는 양파에서 최대
4.46으로 조사되었고, 작물별 큰 차이를 나타내었다. 또한, 동일 작물이라 하더라도 오염물질의 농도 수준, 토양 오염 후 숙성 정 도, 토양의 이화학적 특성, 작물 수확시기 등 여러 요인에 의해 각 연구자가 추정한 $\mathrm{BCF}$ 가 서로 큰 차이가 있었다.

지금까지 알려진 채소류의 작물 흡수이행능과 국내 농경지 토양의 endosulfan 잔류가 여전히 보고되고 있어, 다소비 작물 인 시금치와 당근에서 endosulfan에 대한 토양의 잔류수준별 $\mathrm{BCF}$ 값을 평가할 필요가 있었다. 따라서, 본 시험에서는 endosulfan 토양오염 수준을 Table 1에서 나타낸 것과 같이 서 로 달리하여 $\mathrm{BCF}$ 값을 산출하였다.

\section{시금치의 endosulfan $\mathrm{BCF}$}

시금치는 다소비 엽채소류로 토경 재배를 통해 주로 생산되고 있어, 토양 잔류 오염물질인 endosulfan에 대한 $\mathrm{BCF}$ 에 대한 평 가는 농산물 안전에서 매우 중요한 의미를 갖고 있다. 따라서, 본 연구에서는 endosulfan을 명목상 농도가 $5 \mathrm{mg} \mathrm{kg}^{-1}$ 과 $20 \mathrm{mg}$ $\mathrm{kg}^{-1}$ 이 되도록 저농도 (Treat I)와 고농도 (Treat II)로 오염 된 토양에서 시금치의 $\mathrm{BCF}$ 를 산출하였다. 파종 시 토양 중 endosulfan 잔류농도는 Treat I과 II에서 각각 4.213 과 16.18 $\mathrm{mg} \mathrm{kg}$-1이었으며, 수확일 기준 토양 중 총endosulfan 농도는 Treat I의 평균 잔류농도는 $1.687 \pm 0.253 \mathrm{mg} \mathrm{kg}^{-1}$ 이었으며, Treat II는 $9.627 \pm 1.354 \mathrm{mg} \mathrm{kg}^{-1}$ 을 나타내었다(Table 1). 토양 중 endosulfan sulfate 잔류 기여율은 저농도 시험구인 Treat I에서 $55.5 \%$ 를 나타내었고, 고농도 시험구인 Treat II 는 $34.3 \%$ 를 나 타내어 $\beta$-endosulfan의 잔류기여율과 유사한 것으로 조사되었다. 이는 Hwang 등(2016)의 연구결과와 같이 endosulfan sulfate는 $\alpha$-와 $\beta$-endosulfan의 분해대사물로 시간이 경과할수록 잔류기여 도가 증가한 것으로 보여지며, $\beta$-endosulfan은 $\alpha$-endosulfan 보 다 토양 중 반감기가 길어 나타난 결과로 보여진다.

수확기 시금치의 주당 무게는 평균 Treat I과 II에서 각각 $16.9 \pm 2.1 \mathrm{~g}$ 과 $16.1 \pm 2.1 \mathrm{~g}$ 이었으며, 두 시험구의 시금치 생장량은 유의적 차이를 나타내지 않았다 $(p>0.05)$. 저농도 구간인 Treat $\mathrm{I}$ 에서 총 endosulfan을 기준으로 한 $\mathrm{BCF}$ 는 0.047 이었으며, 고 농도 구간인 Treat II에서의 BCF는 0.040로 나타났다(Table 2). 시금치 내 잔류 endosulfan 중 endosulfan sulfate의 잔류기여율 
이 56-68\% 수준으로 $\alpha$ - 혹은 $\beta$-congener에 비해 2배 정도 높 은 기여율을 나타내었으며, 이는 Mitton 등(2016)이 보고한 여 러 작물 내 흡수 이행된 endosulfan congener의 잔류 분포 결 과와 유사하였다.

\section{당근의 endosulfan $\mathrm{BCF}$}

당근에 대한 endosulfan 흡수이행성 시험은 Park 등(2004)에 의 해 저농도 수준인 $0.3 \mathrm{mg} \mathrm{kg}^{-1}$ 과 $1.3 \mathrm{mg} \mathrm{kg}^{-1}$ 의 오염토양에서 시 험되어, 0.033-0.040의 BCF값을 나타내었다. 따라서 본 시험에 서는 고농도 토양 잔류수준(Treat III)에서 $\mathrm{BCF}$ 를 평가하였다. 명목상 토양 처리 농도는 $21 \mathrm{mg} \mathrm{kg}^{-1}$ 이었고, 숙성 후 파종 시점 의 토양 중 endosulfan 잔류농도는 $18.63 \mathrm{mg} \mathrm{kg}^{-1}$ 이었으며, 수확 시점(파종 후 150 일) 토양 잔류 농도는 $6.751 \pm 0.600 \mathrm{mg} \mathrm{kg}^{-1}$ 이 었다. Park 등(2004)의 시험에서 보고된 바와 같이 endosulfan 의 토양 내 잔류농도가 높아질수록 작물 잔류 수준도 높아짐을 확인할 수 있었고, 본 시험에서 얻어진 당근 가식부와 지상부 의 총 endosulfan잔류량은 각각 $5.323 \mathrm{mg} \mathrm{kg}$ 과 $0.775 \mathrm{mg} \mathrm{kg}^{-1}$ 으로 당근 가식부의 $\mathrm{BCF}$ 는 0.285 이었으며, 뿌리에서 지상부로 의 전이율은 $14.6 \%$ 로 나타났다(Table 2). 이는 endosulfan에 대 한 작물 지상부로의 전이율이 높지 않음을 보고한 Mitton 등 (2016)의 결과와 같았다.

우리나라 농경지 토양에 대한 endosulfan의 잔류 수준은 농 약 등록이 취소된 2012 이전에는 최대 $1.433 \mathrm{mg} \mathrm{kg}^{-1}$ 을 나타냈 으나, 등록 취소 이후 보고된 자료에 따르면 최대 $0.146 \mathrm{mg}$ $\mathrm{kg}^{-1}$ 으로 잔류 수준과 검출 빈도가 크게 낮아진 것으로 조사된 바 있다(Lim 등, 2016a; Lim 등, 2016b). 작물 흡수이행성에 관한 문헌조사결과를 통해 볼 때, 동일 작물이라 하더라도 시 험연구 조건에 따라 $\mathrm{BCF}$ 값은 크게 달라질 수 있으나, 본 연 구에서는 시금치와 당근의 $\mathrm{BCF}$ 값이 최대 0.285 를 초과하지는 않는 것으로 확인되었다. 보다 정확한 결과를 확보하기 위해서 는 동일 품목의 작물이라도 다양한 토양과 품종을 대상으로 시 험하여 $\mathrm{BCF}$ 를 산출할 필요가 있으며, 채소류의 경우 작물 생 장량별 건물 중 endosulfan 농도를 평가하여 수확 시기별 endosulfan 잔류량에 대한 연구가 보완되어야 할 것이다. 특히, PLS제도에서 요구하는 작물 잔류 불검출 기준 $\left(0.01 \mathrm{mg} \mathrm{kg}^{-1}\right)$ 과 동일 작물내 $\mathrm{BCF}$ 편차를 고려한다면, 두 작물을 안전하게 재 배할 경작지의 endosulfan 최대 잔류 농도는 작물 잔류 최저기 준 이하에서 검토되어야 할 것으로 판단된다.

\section{초 록}

Endosulfan은 스톡홀름협약을 통해 잔류성유기오염물질(POPs)로 지정되어 생산 및 사용이 금지되었으나, 여전히 국내 농업환경 에서 검출되고 있고, 이로 인한 작물잔류는 사회적으로 큰 문 제가 되고 있다. 따라서, 경작지 잔류 endosulfan으로부터 안전 한 농산물을 생산하기 위한 작물흡수이행능 평가는 매우 중요 하다. 본 연구에서는 문헌조사를 통해 지금까지 보고된 endosulfan의 생물농축계수 $(\mathrm{BCF})$ 를 조사하였고, 당근과 시금치 의 $\mathrm{BCF}$ 를 시험을 통해 검증하였다. 문헌조사결과 endosulfan의 $\mathrm{BCF}$ 는 0.002-4.460으로 작물별, 재배지역별 차이가 크게 나타 났으며, 실험을 통해 검증한 당근과 시금치의 $\mathrm{BCF}$ 는 0.285 와
0.040-0.047로 각각 나타났다. Endosulfan 중 작물에 주로 잔류 하는 이성체는 endosulfan sulfate로 확인되었다.

Keywords 당근 - 생물농축계수 - 시금치 - 식물흡수이행 - 엔도 설판

Acknowledgment This study was carried out with the support of "Cooperative Research Program for Agricultural Science \& Technology Development (Project No. PJ01143506)", Rural Development Administration, Republic of Korea.

\section{References}

Ahn JH, Park I, Kim WG, Han BH, You J (2017) Effect of an organochlorine insecticide, endosulfan on soil bacteria community as evaluated by $16 \mathrm{~S}$ rRNA gene analysis. Korean J Pestic Sci 21: 1-8

Choi CM, Yook DH, Hong CK, Kim TR, Hwang YS, Hwang IS, Kim JH, Kim MS, Chae YZ (2011) Monitoring of residual pesticides in agricultural land from the Southern area of Seoul. Korean J Pestic Sci 15: $160-165$

Choi GH, Lee DY, Jeong DK, Kuppusamy S, Lee YB, Park BJ, Kim JH (2017) Perfluorooctanoic acid (PFOA) and perfluorooctanesulfonic acid (PFOS) concentrations in the South Korean agricultural environment: A national survey. J Integr Agric 16: 1841-1851

Esteve-Turrillas FA, Scott WC, Pastor A, Dean JR (2005) Uptake and bioavailability of persistent organic pollutants by plants grown in contaminated soil. J Environ Monit 7: 1093-1098

Hwang JI, Lee SE, Kim JE (2015) Plant uptake and distribution of endosulfan and its sulfate metabolite persisted in soil. PLoS ONE 10: e0141728

Hwang JI, Kwak SY, Lee SH, Kang MS, Ryu JS, Kang JG, Jung HH, Hong SH, Kim JE (2016) Establishment of safe management guideline based on uptake pattern of pesticide residue from soil by radish. Korean $\mathrm{J}$ Environ Agric 35: 278-285

KOSIS (2017) Crop production survey. In Korean Statistical Information Service, Statistics Korea. Website available: http://kosis.kr/statHtml/ statHtml.do?orgId=101\&tblId=DT_1ET0028\&vw_cd=MT_ZTITLE\&lis $\mathrm{t} \_\mathrm{id}=\mathrm{F} 1 \mathrm{H} \&$ seqNo$=\&$ lang_mode $=$ ko\&language $=$ kor\&obj_var_id $=\& \mathrm{itm}$ $\overline{\mathrm{id}}=\&$ conn $\_$path $=\mathrm{E} 1$. Accessed 8 Aug 2017

Lee BR, Lee HK, Lee KH, Yoon SS, Kim M, Park JW, Jeong SH, Lee MH, Bae YC (2013) Devastating endosulfan poisoning in Korean native cattle. Korean J Vet Res 53: 269-271

Lim SJ, Oh YT, Ro JH, Yang JY, Choi GH, Ryu SH, Moon BC, Park BJ (2016a) Investigation of residual organochlorine pesticides in green perilla (Perilla frutescens var. japonica Hara) greenhouse soil and its leaves. Korean J Pestic Sci 20: 221-227

Lim SJ, Oh YT, Jo YS, Ro JH, Choi GH, Yang JY, Park BJ (2016b) Persistent organic pollutants (POPs) residues in greenhouse soil and strawberry organochlorine pesticides. Korean J Environ Agric 35: 6-14

Manirakiza P, Akinbamijo O, Covaci A, Pitonzo R, Schepens P (2003) Assessment of organochlorine pesticide residues in West African city farms: Banjul and Dakar case study. Arch Environ Contam Toxicol 44: 171-179

Mitton FM, Gonzalez M, Monserrat JM, Miglioranza KSB (2016) Potential use of edible crops in the phytoremediation of endosulfan residues in soil. Chemosphere 148: 300-306

NAQS (2017) 2017 Annual report of national residue survey. National Agricultural Products Quality Management Service. Website available: http://www.safeq.go.kr/news/news/news.do. Accessed 8 Aug 2017

Park HJ, Choi JH, Park BJ, Kim CS, Ilm YB, Ryu GH (2004) Uptake of endosulfan and procymidone from arable soil by several vegetables I (green house study). Korean J Pestic Sci 8: 280-287 